\section{B A Institute of \\ YK Business Administration \\ 六下 \\ Karachi \\ Leadership and Ideas for Tomorrow}

Business Review

Volume 9 Issue 2 July-December 2014

$7-1-2014$

\title{
Corporate governance and cash holdings in listed non-financial firms in Pakistan
}

\author{
Alina Masood \\ Institute of Management Sciences, Peshawar, Pakistan \\ Attaullah Shah \\ Institute of Management Sciences, Peshawar, Pakistan
}

Follow this and additional works at: https://ir.iba.edu.pk/businessreview

Part of the Accounting Commons, and the Corporate Finance Commons

c) (i)

This work is licensed under a Creative Commons Attribution 4.0 International License.

\section{Recommended Citation}

Masood, A., \& Shah, A. (2014). Corporate governance and cash holdings in listed non-financial firms in Pakistan. Business Review, 9(2), 48-73. Retrieved from https://doi.org/10.54784/1990-6587.1271

This article is brought to you by iRepository for open access under the Creative Commons Attribution 4.0 License and is available at https://ir.iba.edu.pk/businessreview/vol9/iss2/5. For more information, please contact irepository@iba.edu.pk. 
https://ir.iba.edu.pk/businessreview/vol9/iss2/5

DOI: https://doi.org/10.54784/1990-6587.1271

Business Review - Volume 9 Number 2

July - December 2014

\title{
ARTICLE
}

\section{CORPORATE GOVERNANCE AND CASH HOLDINGS IN LISTED NON-FINANCIAL FIRMS IN PAKISTAN}

\author{
Alina Masood \\ Institute of Management Sciences, Peshawar, Pakistan \\ Attaullah Shah \\ Institute of Management Sciences, Peshawar, Pakistan
}

\begin{abstract}
In this study, the relationship between corporate cash holdings and corporate governance variables is tested in Pakistan. The sample consists of 309 non-financial firms listed on the Karachi Stock Exchange (KSE) over the time span of 2002 to 2010. The study uses several proxies for corporate governance mechanisms such as percentage ownership held by directors, institutional investors, and five largest shareholders, the existence of audit committees and a measure of concentration of ownership. To avoid omitted variable bias, the study also controls for all well-known determinants of corporate cash holdings (market to-book ratio, growth, size, leverage, $R \& D$ investments, cash flow volatility and cash flows). The two main findings of the study are (i) director's ownership and board size are negatively related with corporate cash holdings. The institutional shareholdings, concentration of shares and the ownership percentage of 5 big shareholders are directly related to cash holdings. (ii) Among the control variables, growth and size are insignificant while dividend and cash flows are positively associated with cash holdings and leverage, capital expenditure and net-working capital are negatively related to cash holdings. The findings imply that managers of the firms do not misuse the cash when more monitoring and control is involved by the shareholders. The results also indicate that cash holdings by the firms are maintained for the dividend payments. Finally, debt and working capital act as a cash substitute for firms which lead to less cash holdings.
\end{abstract}

Keywords: Cash Holdings, Corporate Governance, Non-financial firms, Karachi Stock Exchange

\section{Introduction}

There is a considerable amount of literature that has thrown light on the relationship of corporate governance and cash holdings of firms. There are studies that emphasize the significance and the determinants of the corporate governance and cash holdings separately while on the other extreme there are studies that emphasize the relationship between the two variables together. The meta analysis that have focused on the corporate governance mechanism of the firm's include Estrin (1999), Xu and Wang (1999), La Porta, Lopez-deSilanes, Shleifer and Vishny (2000), Johnson (2000), Bertrand, Marianne and Mullainathan (2003), Bebchuk, Cohen and Ferrell (2004) and Isshaq et al. (2009). 
Firms around the world have a system that controls the ways in which stakeholders interact with each other. This system is known as corporate governance. The objectives of firms are set, achieved and monitored under this system. La Porta, Lopez-de-Silanes, Shleifer and Vishny (2000) defined corporate governance as, "Corporate governance is a set of mechanisms through which outside investors protect themselves against expropriation by the insiders". They further defined "the insiders" as both managers and dominating shareholders of firms.

Recently,a number of studies have looked into the impact of corporate governance on the cash holdings at firms' and countries' level. These studies include Dittmar et al. (2003), Kusnadi (2006), Harford et al.,(2006), Kalcheva and Lins (2007), Chen (2008), Pinkowitz et al. (2004) Kuan et al., (2009) and Ammann et al. (2010). Generally, it is a known fact that cash and cash equivalents are an important part of the current assets of the firms (Kusnadi, 2005).Studies by Keynes (1936), Jensen and Meckling (1976), Myers (1984),Jensen (1986), Myers and Majulf (1986) have discussed the costs and benefits of cash holdings by firms. On the empirical front, studies by Opler, Pinkowitz, Stulz and Williamson (1999) and Kim, Mauer and Sherman (1998) examined the effects of various financial variables on the amount of the cash held by firms. More recently Saddour (2006),Kalcheva and Lins (2003) studied the determinants and the value of cash holdings. The study by Opler et al. (1997) suggests that determining the optimal level is difficult but an important financial decision.

Firms hold cash with themselves for many reasons or motives. Foremost is to meet the day to day requirements, secondly as a precautionary measure that is for the safety of firms (Keynes, 1936). Holding of cash is a double edged sword for firms (Ammann, Oesch and Schmid, 2010). This means that there are many costs and benefits that are associated with it. The costs include agency costs, i.e. more cash holdings by a firm create conflict of interest between the managers and the shareholders. If the rights of outside shareholders are not protected, then managers might use the cash in their own interest, resultantly potential investors will not invest in such firms (La Porta et al., 2000 and Dittmar et al., 2003). This raises the question of whethera firm needs to hold more or less cash. Holding cash is important for the firm but it should not be in excess reserves because cash is a least productive asset in terms of generating economic returns coupled with its role in exacerbating agency problems. According to the Wall Street Journal, cash holdings by firms have increased from 10.5\% in 1980 to $23.2 \%$ in 2006 (Bateset al., 2009).As witnessed, by theend of 2004, the cash holdings of some of the well-known firms like Microsoft, General Motors Ford, General Electric, Exxon Mobile and Pfizer were $\$ 60.6$ billion, $\$ 36.0$ billion, \$33.4billion, \$23.2 billion, \$23.1 billion, and \$19.9 billion, respectively (Foley et al., 2007). Similarly in Pakistan Oil and Gas Development Company (OGDC) and the Fauji Fertilizers Company (FFC) hold large amount of cash with them. The cash reserve of OGDC and FFC in the year 2003 was Rs.19 billion and Rs.3.1 billion respectively. This amount increased to Rs.25 billion and Rs.4.1 billion in the year 2004 respectively (Shah, 2011). As literature shows, greater holdings requires good governance, otherwise extra cash holdings might give incentives to managers to use the cash in a less than optimal manner. Thus, in firms where governance is not up to the mark excess cash is mismanaged and can destroy the firm value. So, firms should maintain an optimal level of cash for themselves (Kim et al., 1998).

There are a negligible number of studies in Asian countries especially in Pakistan on the given topic. More recently the areas of corporate governance and cash holdings 
individually have received attention of researchers. In the area of corporate cash holdings and its determinants in Pakistan, the work by Afza and Adnan (2007), Azmat (2011) and Shah (2011) are noteworthy as they took a larger sample of firms listed on the Karachi Stock Exchange (KSE). The corporate governance and its effect on other financial variables is documented in the work by Mir and Nishat (2004), Naqvi and Ikram (2004),Javid and Iqbal $(2008,2010)$. All the studies in Pakistan are either in the areas of governance mechanism or the cash holdings separately. The present study is a step toward studying the two factors together in Pakistan. Thus, the present study makes its contribution to the extant literature by examining the effect of the corporate governance on the cash holding decisions of the nonfinancial listed firms listed on the Karachi Stock Exchange (KSE) over the time span of 2002 to 2010 .

\section{Literature Review}

This section provides a review of the literature on the topic under investigation. It has been divided into three parts. The first part reviews the dominant theories of the cash holdings proposed by different researchers in their studies. The second part reviews the conceptual and empirical findings on the link between cash holdings and the corporate governance. The third part focuses on the literature of corporate governance and cash holdings in Pakistan.

\subsection{Cash Holding Theories}

Companies need cash for a variety of motives. However, holding cash is not extremely important for the companies because when they need cash for financing the profitable projects, they have the option of obtaining it from the capital market (Saddour, 2006). There are many theories that explain the reasons for holding cash by firms.

\subsubsection{Motives to Hold Cash}

The most important study by Keynes (1936) is the "The General Theory of Employment, Interest and Money", in which he described three motives to hold cash. Firms hold cash for the motive of transaction i.e. due to meet the day to day operational cash requirements to purchase goods and services. Secondly due to precautionary motive i.e. investing in cash is much safer besides this cash does not lose its value. Third, the speculative motive i.e. investments in cash provides a return to their holders.

\subsubsection{Trade off Theory and Pecking Order Theory}

Literature shows that these two theories have some implications in the cash holdings decisions by firms. In the trade off theory the optimal level of the cash is determined after analyzing the benefits and the costs of holding the cash with the firms. Some of the benefits are that cash enables firms to take and continue the projects without raising external funds that are at high transaction costs, to pay dividends and not to reduce it when they face cash shortages. The costs associated to hoarding cash by the firm involves whether managers boost shareholders wealth or not. If their decisions are in the interest of shareholders then the only cost of holding cash is its lower return as compared to other investments that are equally risky (Saddour, 2006). The cash holdings will be more costly and include the agency cost. This increases the power of the managers. If managers do not increase shareholders wealth then they will increase their cash holdings, so as to increase assets under their control. This in turn increases the power of the managers (Saddour, 2006 and Jensen, 1986). The majority of the studies such as Opler et al. (1999) and Kim et al. (1998) in the USA confirmed that the 
tradeoff theory exists and researchers have found evidence that firms in countries with greater investor protection and better capital markets hold less cash. This is because when companies need cash for financing the projects that are profitable they usually go to the capital market for it.In the pecking order theory by Myers (1984)new equities are very costly to issuedue to informational asymmetry. Thus initially firms finance their investments with internal funds then with debt and finally come towards the equity financing (Myers, 1984; Myers and Majluf, 1984). Similarly Kalcheva and Lins (2003) confirmed the pecking order theory. These two theories play a significant role in explaining the determinants of cash holdings in the 297 French firms in the year 1998 to 2002 (Saddour, 2006). The growing firms hold higher levels of cash than mature firms and this is because different investment opportunities have to be accepted by them without external financing that is costly (Saddour, 2006).

Similarly in Pakistan, Shah (2011) confirmed that the growing, large and dividend paying firms along with firms with more cash inflows have more cash than other firms. While the firms with longer debt maturity hold less cash. He suggested the motives of cash holdings given by Keynes were applicable to the Pakistani firms.

\subsubsection{Free Cash Flow Theory}

In free cash flow theory by Jensen (1986) managers want to hold more cash so as to exercise more power in decisions regarding investments. With high cash levels by firms the need to take external finance decreases and thus managers could investment in non-profitable projects like acquisitions which decreases wealth of the shareholder(Lang et al., 1991; Blanchard et al., 1994; and Harford et al., 1999).Increase in free cash flow is associated with increase in agency conflicts that is between management and shareholders. In particular, managers are involved in overinvestment, consumption of private benefits, or simply holding of the cash for their own interests documented by Jensen (1986).

\subsection{Cash Holding and Corporate Governance}

The cash holdings and its determinants have been discussed, the study will explicate the literature analyzing the relationship regarding the question of whether corporate governance has an impact on the cash holdings of the firms. Through governance mechanisms minority outside investors are protected from the powerful managers and dominant shareholders inside the firm (La Portaet al., 2000). It is the definition of the shareholders interest (Jean Triole, 2001). Studies have shown that the cash holdings decisions of the firms are dependent on their governance mechanisms.

Chen (2008) suggested that the impact of the governance on the cash holdings of the firms that face different opportunities for investment by analyzing 1,500 American firms from 2000 to 2004. He took two types of firms, the old economy and the new economy firm. The firms in the software, internet, and telecommunication industries are considered to be new firms and have more opportunities of investment. They also need a larger amount of capital for investment purposes. These firms hold more cash as they require it and use it for the research and the development purposes. In contrast, firms in the manufacturing industries such as manufacturers of durable and non-durable products do not have good opportunities of investment. Chen (2008) found that new economy firms have more opportunities as compared to the older firms and needs more cash to hold. This is the reason that the governance mechanisms in the new economy firms are protecting the shareholders and in turn the investors are willing for the increase amount of cash to hold. The impact of the governance and cash holdings also create the agency problems between the managers and the 
shareholders for the optimal level of cash. The governance mechanism is different in the two firms. Chen (2008) further found that the two different firms have different characteristics and that results in different governance. This in turn affects the policy that the firm develops and that includes the decision of cash holdings of the firms. Furthermore the board of directors is an important internal governance system. Its role is to monitor and to confirm the accuracy of information that is released to shareholders. An independent board reduces managerial control, increase monitoring thus the agency conflicts decreases. In addition to this, it also increases the board efficiency in directing the business operations. In the study by Chen (2008) the evidence showed that higher managerial ownership will reduce cash holdings in old economy firms and higher board independence increases cash holdings in listed new economy firms. According to Chen (2008) the new economy firms are taking more risky projects and have high opportunities of investment and volatile cash flows, while they have difficulty in obtaining the external financing. The independence of the board gave a surety that the company has invested its cash appropriately. The holding of the cash by the firms (in both old economy and new economy firms) will be affected by the governance. However when the shareholders are not protected by the country and have less legal protection then it results in the agency problem and more power to the managers. Where managers had the control and the shareholders are less protected then the firm value is decreased and the managers have more control leading to them holding more cash (Kalchevaand Lins, 2007). In addition to this when the firms hold more cash as the rights of the shareholders are less protected, the amount of the holdings is twice as large as compared to those countries that protect the shareholders rights. When the shareholders are not protected then managers enjoy more power and use the excess cash for their own interests. This results in weak governance and in turn polices of the firms like the cash holdings are affected (Jensen and Meckling, 1976).There is strong evidence that corporate governance effects the firms' decision to have cash holdings and the levels that are maintained. So, when the corporate governance is poor then firms hold more cash (Dittmar et al., 2003). Although in the US firms when managers are not monitored they are engaged in the activities that will not be for the shareholders wealth maximization. In addition to this the firms having less managerial ownership, affects the behavior of the firms, as mangers have no incentives to work for the shareholders benefits, this results in weaker governance (Bertrand and Mullainathan, 2003). While in the following year Pinkowitz et al. (2004) found that countries where there is less protection of investors' rights, less cash is held and managers could use the resources of the firms for their own interest. Likewise Couderc (2005) documented the determinants and consequences of the corporate cash holdings using 4515 firms. The countries that were taken for the analysis were Canada, France, Germany, UK and USA. The firms having volatile cash flows had more cash holdings than other firms. This shows that when more cash is held by the firms it results in bad performance. Thus Couderc (2005) suggested that bad corporate governance results when larger amount of cash is hoarded. Thus cash is misused by managers and is not utilized in the profitable projects. On the other hand if these firms utilize their cash holdings in the profitable projects they will have to give higher dividends to its investors to protect them. In contrast to the findings of most of the studies Harford et al. (2006) documented positive relationship between the two variables in 1872 American firms. The firms that have weak corporate governance system have fewer amounts of cash with them as reserves. In contrast of the well governed firms these firms disperse their cash reserves quickly. Along with this they do not utilize cash internally, they spend more on acquisition. The firms having weak governance have low insider ownership, less shareholders rights and independent boards, their value and profitability in future decreases when they invest internally or externally. 


\subsection{Corporate Governance and Cash Holding Relationship in the Asian Countries}

After analyzing the relationship in developed nations the study evidences this relationship in the Asian context. The review of literature shows that the Asian firms hold more cash. An influential study by Kusnadi (2003) on230 Singapore firms publically listed on the stock exchange of the country documented that the board size and the cash holdings are positively related with one another. While an inverse relation is displayed between of the cash holdings and the non-management block shareholders ownership, who are the non-executive directors of the companies and hold more than $5 \%$ stake of the companies. This showed that the poorly governed firms have high board size and less non-management block ownership. He further documented that this is discouraging for the shareholders and makes them powerless to force the managers for the distribution of the surplus cash. The inverse relationship between the board size and the non-management ownership means that there is lack of the monitoring in Singapore firms. In short, poor governance leads to poor management polices one of which is the cash holdings. In addition to this Kusnadi (2006) extended the work and took 455 firms listed in Singapore and Malaysia. The firms having weak corporate governance and powerful managers have more cash holdings. According to Kusnadi (2006) managers of the poorly governed firms are more powerful for making cash policies. This is because they have fewer incentives to distribute the excess cash back to the minority shareholders. Further more Kusnadi (2011) found the positive effect of governance and holding variables on the firm performance. The reason for this relationship is that good governance leads to good performance of the firms. In another important study by Kuan et al. (2009) who found that the publically listed firms in Taiwan have higher agency problems, which means that the governance in Taiwan is weak and thus firms hold more cash with them. Soltani and Ravanmehr (2011) analyzed 75 listed companies on the Tehran stock exchange over a period of 2002 to 2009 and documented that shareholders in Tehran believes large cash holdings by firms leads them to utilize the cash in profitable projects and R\&D expenditures. Furthermore the study emphasizes the fact that the outside directors results in more monitoring and control to the firms. While the inside directors enjoy less control and thus the share prices increases in turn the value of the firm increase. While in the following year Tsai (2012) examine the topic under investigation in Tehran using companies listed on stock exchange over the period 2005 to 2009. The study found that the business group affiliated firms means that the company related to other company in the business group, have good governance have high opportunities for growth, have more cash with them and their size is small. This means that the firms that have good governance will have a small size, as managing on a smaller scale is better than on alarger level and thus will go towards the profitable investment in the business group. They will then hold more cash so as to take the projects that are generating more return. Ping et al. (2011) emphasized the relationship between corporate governance and cash holding variables along with the firm performance in China. The noteworthy point is that the researchers are of the view that corporate governance in China is not perfect and that is the reason that more cash is held by the Chinese firms. It is due to lack of monitoring and control on the managers' activities and thus the interests of the managers and the shareholders are not in line with one another. They further showed that the independent directors do not play their role in Chinese firms and are more involved towards cash reserving. Lee and Lee (2009) who explored the relationship between the cash holdings and one of the proxies for corporate governance from the year 2001 to 2005in the firms of Malaysia, Singapore, Thailand, Philippines and Indonesia. They found that the relationship between the cash holdings and the board structure i.e. the board size, its independence and the 
managerial ownership, is negatively related to one another in the Asian countries. Thus when corporate governance is low more cash is held by the firms in the five big Asian counties. The reason is that larger and independent board leads to more the monitoring and thus stronger decision making power is with the board. So, the managers of these firms will not use the cash for their personal benefits or in non-profitable projects. This results in fewer amounts of cash held by them. Lee and Lee (2009) further documented that the managerial entrenchment and their ownership will decrease.

The researchers made comparisons between the relationships of corporate governance and cash holdings of different Asian counties in many studies. One such study is by Paskelian et al. (2010)in India and China. These two important Asian countries are the emerging markets of the world. The study analyzes 1164 Chinese and 334 Indian firms over 14 year and 5 year period respectively. The outcome of the study showed that the Chinese firms had higher government ownership and higher cash holdings. This means that the board is not independent in making decisions regarding the firm's policies. The cash reserves are used for the personal benefits in the firms. Indian firms were mostly owned by families with lesser cash holdings than Chinese firms. This means that the conflicts between the shareholders and the managers are not arising and agency problems are low. Thus there is no extraction of the personal benefits, as the firms are owned by families.

Until now the literature showed the relationship of the two variables in the Asian and the international context. Now the present study discusses the comparison of the relationship between the corporate governance and cash holding decisions in the developed and the developing countries. The literature shows that there are differences in the relationship between cash holdings and the corporate governance in the developed and the developing countries the extremes of the world. These differences are due to the situations that prevail in these two extremes. Like in one of the developing countries Iran Valipour et al. (2012) examined 79 firms from the year 2001 to 2009 and documented that the cash held by the firms in the Iran are not affected by the board structure and its independence. The reason is that cash holding polices in Asian countries specifically are mostly influenced by the government and the political situations of the country. Same is the case in Iran. The decision of the holding cash varies according to the firms characteristics. A general point that is observed is that governance is not good in the firms of developing counties which in turn affects the significant policies and the decisions of the firms and one such important decision and policy is the amount of cash hoard by firms. The problems prevailing in the developing countries that affect the relationship are corruption, the political situations, and law and order situations of country. The study by Chakrabarti et al. (2008) documented some of these differences by explaining the corporate governance of one of the developing country India and compared it to the governance of developed countries US and UK. They found that governance in firms is not good due to all the problems that are discussed previously. The minority shareholders are not well protected in the environment where the legal system is not strong enough and there is judicial inefficiency. Thus investors are not encouraged to invest in firms. In another study by Sarkar and Sarkar (2000) found that large shareholdings influence corporate governance in both the developed and the developing nations equally. The main differences that occur are the less develop capital markets in the emerging countries, more dependence on the external resources for the financing and there are no managerial markets in these counties. Similarly in India Hothi et al. (2011) found that firms in India and their governance are different than those of the developed countries of the world. It is due to the fact that there are differences; the conflict is between the dominant shareholders 
and the minority shareholders. The minority shareholders rights are not well protected in the developing countries due to weak legal system (Pinkowitz et al., 2006 and Kalcheva and Lins, 2007). The corporate governance is responsible for the internal organization as well as to fulfill the external social and the economic needs of the country. Furthermore, mostly the Asian firms are controlled by a single and large shareholder (Claessens et al., 2000) and this might reduce the monitoring by external large shareholders. In a study by Ginglinger and Saddour (2007) using French firms as a sample over time span of 1998 to 2000 found that governance mechanism and the cash holding of the financially constrained firms are positively related. They documented that low governance leads to low cash holdings by firms. The firms in less developed countries where governance is low are financially constrained, and therefore hold more cash (Khurana et al., 2006). EhikioyaYuanjian (2007) for analyzing the relationship between the two variables under investigation took the Nigerian listed firms from 2001 to 2005. The findings of study suggest that corporate governance has the same affect and the influence on the cash holding policies on Nigerian firms like the other Asian countries. They further describe that poorly governed firms in Nigeria hold more cash as compared to the good governed firms. The rationale for this is that the managers have more power and dominance in the Nigerian firms and hold more cash. The cash creates the managerial opportunism. Besides this, there is lack of monitoring on activities ofmanagers. The reason is that there are no incentives given for monitoring, so managers are free and have the decision making powers a about the significant policies of the firms. The same relation is found by Schauten et al., (2011) in the European countries. The impact of the corporate governance on the cash holdings of the larger firms is European firms is the same like the other developed countries. The good governance protects the minority shareholders from the management and the majority shareholders and this in turn increases the value of the firms. Varma (1997) made the comparison of the relationship between the two variables under investigation in India and found that there are differences in the developing country and the developed countries like US and UK. He documented that in US or UK firms a conflict arises between management and firm owners, when the management is not working satisfactory and is not providing answers to the owners. This problem could be solved when the board of directors takes interests in decisions and policies regarding firm. He further explains that contrary to this in India the problem is there between the dominant and the minority shareholders rights. This could be resolved by the power that is external to the firms like the regulatory bodies. Consistent with the findings of previous studies Zhang (2005) took 3000 listed companies from 21 countries, both Asian and European countries and found that more inside directors have the power, the more they will hold the cash and poor governance will follow. The reason is that the managers use the cash for their personal benefits. The important policies like the cash held by the firms are mostly influenced by the legal environment in which the firms are operating. Johnson et al. (1999) conducted a study in to explain the Asian crises 1997-1998. The researchers argued that corporate governance is a much better measure of the stock market decline and the depreciation in Asian crises rather than the macro economic variables. The reason behind this is that the Asian countries have less judicial efficiency, the shareholders rights are also not protected well, political instability and corruption which leads investors to lose confidence. When the investors are not confident about their investments they will be reluctant to invest in such an environment where the legal system is not strong enough to support them. The governance in the companies of Asian countries is also dependent on these factors and hence cannot make their own strong decisions. The developing countries which are considered as the emerging markets do not have perfect corporate governance documented by Gibson (2002). However he further argued 
that CEO of the firm is fired out of the job if the firm performance is low and on the other hand firms in which there is domestic ownership the CEO is not fired so the balance of the effective and ineffective governance is maintained in the Asian firms. Most of their decisions and most importantly their governance are influenced by the government.

These studies shows that the relationship between cash holdings and corporate governance of the firms in developed and the developing countries are the same however the situations and the conditions that are affecting this relationship are different in the two parts of world. In the developing countries there are problems like corruption, political influences, less protection for the minority shareholders, more dominant family owned businesses, etc.

\subsection{Evidence from Pakistan}

This section of the study focuses on discussing cash holdings particularly in the Pakistani context. Azmat (2011) examined the cash holding determinants in Pakistani firms. Two groups of firms were taken in order to know whether growing firms or the matured firms hold more cash. For the whole sample, higher cash holdings results when firms have high cash flows, capital expenditures, cash flow volatility and decrease their cash levels when they have liquid assets, substitutes of cash, leverage and larger amount of fix assets. Growing firms hold more cash as they find external financing more costly and because they want to avail potential projects (Shah, 2011).Contrary to these findings another study found that the cash held by mature firms are due to the fact that they want to increase the resources and also to utilize the amount in projects that are not so profitable. So, the cash holdings of growing firms are almost double than that of mature firms (Azmat, 2011). Similarly Afza and Adnan (2007) argued that firms have to maintain certain amount of cash with them for the purpose of reinvestment, or to give to the shareholders as dividend payments. They found that size, cash flow, cash flow uncertainty of non-financial firms in Pakistan affect cash holdings positively while investment opportunities, leverage, dividend payments and liquid assets are negatively related. These findings indicate that the firms in Pakistan hold more cash for financing and investment that result in agency problems in firms. In addition Shah (2011) documented a positive relation between the cash holdings and the size of firms, leverage and cash flows. He further documented that Profitable firms in Pakistan that are paying dividend by following a pattern and have high cash inflows hold more cash with them.

In the present section the review of different studies is discussed. At first theories of cash holdings (free cash flow, pecking order and trade off theory) that explained reasons for cash held by firms is discussed followed by the relationship between the corporate governance and cash holdings in different researches internationally and in Asian countries is discussed. The review of literature showed that the corporate governance and cash holdings are directly related while in other researchers an inverse relation is observed. Finally researches of cash holdings in Pakistan are discussed. In the following section the present study by taking a sample of firms in Pakistan will find a relationship between the corporate governance and cash holdings.

\section{Methodology}

This section discusses the data, its sources and sample size that is taken for analyzing the relationship of the variables of present study. Followed by definitions of independent and dependent variables and their measurement criteria are discussed. Finally the statistical model selected for the study is discussed. 


\subsection{Sample and Sources of Data}

The sample of study consists of the non-financial firms listed on the KSE over the time span of 2002 to 2010. The sample period starts form 2002 as in this year the code of corporate governance was formed in Pakistan and required firms to report corporate governance data in their annual reports from 2002 onwards. Consistent with the literature, the study excludes the financial firms listed on the KSE(Shah, 2011; Kuan et al., 2009 and Kusnadi, 2011). The reason is that their capital structure and profits are different.

The sources of the data used in the study are the annual reports of the listed firms. In Pakistan, existing studies such as Cheema et al. (2003), Javid and Iqbal (2008, 2010), Azmat (2011) and Shah (2011) have used different variables from the annual reports for the proxies of corporate governance and the other financial variables. Some of thevariables in these researches are concentration of ownership, growth opportunities, dividend payments, leverage, cash flow volatility, cash flow, investment, size, capital expenditure, and net working capital.

\subsection{Definition of Variables}

Following the earlier literature (Kim et al., 1998; Opler et al., 1999; Dittmar et al., 2003; Drobetz et al., 2004; Saddour, 2006; Harford et al., 2006; Kusnadi, 2006) variables are defined as follows.

\subsubsection{The Dependent Variable}

Like the prior studies by Dittmar et al.(2003),Harford et al.(2006), Pinkowitz et al. (2006), Kusnadi (2006), Chen (2008), Ammann et al. (2010) and Kuan et al.(2011) the dependent variable that is used in this study is the cash holdings (CASH) of the firms. This is measured as a ratio of cash and cash equivalents to net assets. Net assets are computed as total assets less cash and cash equivalents.

\subsubsection{The Independent Variables}

The independent variables include different proxies for corporate governance and a set of control variables. The proxies of the corporate governance in the study are the ownership structure and board structure (Kuan et al., 2009; Chen, 2008; Harford et al., 2006).

\section{Ownership Structure}

The ownership variables consistent with previous literature are the institutional ownership(INST), director ownership(DIRC), and a measure of ownership concentration $(C O N)$. The institutional shareholding (INST) is the shares held by the institutional investors divided by total shares. These institutions are the financial institutions and non- financial corporations. Another proxy is the director's ownership (DIRC) which is measured as the shares held by the directors divided by the total number of shares. The variable concentration $(C O N)$ is the log of the number of shareholders. The firms that have more shares held by the directors and having concentrated ownership will have better alignment of interest and monitoring which in turn will result in less agency problems. (La Porta et al., 2000;Kusnadi, 2006; Kalcheva\&Lins, 2007; Chen, 2008).

\section{Board structure}

Broad structure includes the variables board size and board independence. The board size variable is defined as the number of directors on the board (BOARD). Likewise the shares 
held by the 5 largest shareholders of the firm $(B I G)$ is included as the independent variable to proxy for corporate governance in line with the study by Lee and Lee (2009),Chen (2008) and Kusnadi (2006).

\subsubsection{Control variables}

The control variables included in the study which explain variation in the cash holdings of firms are consistent with Kusnadi (2006), Harford et al. (2008), Opleret al. (1999), Chen (2008), Kuan et al.(2009), Ammann et al.(2011). These variables include growth that is the geometric mean of the percentage increase in the total assets (GROWTH).The control variable, dividend is a dummy variable i.e. firms that pay dividend $=1$ and those not paying dividend $=0(D I V D U M)$. Firms cannot pay dividends when they are in need of cash. It acts as a substitute of cash for the firms. The log of total assets is the size of firm (LOGSIZE).Literature shows that the smaller the firm size the larger the problem of information asymmetries as well as more financial constraints and thus they are more likely to suffer from financial distress (Kuan et al., 2010 and Kusnadi, 2004).The variable leverage is for the financial health of the firms and represents the financial risk that firms face. It is measured as the ratio of total liabilities to total assets (LEVE). For controlling the potential investment opportunities the variable capital expenditure is the percentage increase in the gross fixed assets $(C A P E X)$. For the liquidity of the firms consistent with the studies of Kim et al. (1998), Harford (1999), Opler et al. (1999) and Dittmar et al. (2003), the ratio of current assets minus cash minus current liabilities to total assets is the networking capital $(\mathrm{NW} C \mathrm{CASH})$. Cash is deducted from this ratio because variable cash is dependent (cash holdings) and at the same time is included in the independent variables (working capital). This variable captures and controls for the additional liquid assets that are held by the firm. It is equal to or a substitute for cash and equivalents. In order to control for the profitability of the firms the variable cash flows (CASHFLOWS) is the ratio of addition net income and depreciation to the total assets.

Table 3.1 presents the list and measurement of the dependent, independent variables and control variables that are used in the present study in light of the discussion in the literature review section.

\subsection{The Model}

The empirical model estimated in light of the theoretical framework of the study is

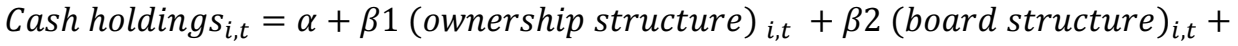
$\beta$ (control variables) $)_{i, t}+\varepsilon_{i, t} \quad$ (eq1)

In the above model the cash holdings of the firm $i$ at time $t$ is the dependent variable and the independent variables are the ownership structure, the board structure and a set of control variables. $\varepsilon$ is the error term.

The relationship between corporate governance and cash holdings is tested using regression technique. Panel data analysis is used in this study because the data has time series as well cross-sectional properties. The most important motivation for using panel data is that it allows controlling for unobserved heterogeneity. Furthermore this technique has more variability, less collinearity, more degrees of freedom and estimates are more efficient. Panel data increases the sample size and assists in studying more complicated models. For the purpose of analysis the panel regression models that are pooled regression, fixed effects and the random effects model are discussed in the following part (Cameron, 2007). The 
techniques mostly used for panel data analysis are fixed effect and random effects models which are discussed below (Gujarati, 2003).

\subsubsection{Pooled Regression}

Pooled regression is usually carried out on time-series cross-sectional data. It is a part of the panel family of regression models. This technique is mostly used when the data is homogeneous (Joseph, 2010). While in the present study the groups are heterogeneous and therefore more complex and advance models that are random and fixed effects are used for the analysis of data (Joseph, 2010).

\subsubsection{The Fixed Effect Regression Model}

Fixed effects models measure differences in intercepts for each groups calculated using a separate dummy variable for each group. This is basically an OLS model with dummy variables to control for group differences, assuming constant slopes (coefficients) for independent variables and constant variance across groups. It increases the degrees of freedom (Greene, 2006).In the present study the fixed effects regression model is used. This model is given by Mundlak (1961). The rationale for using the fixed effect model in the present study is that firms have some unique characteristics that are known to the firm but no other individuals. These unobservable factors need to be taken into account. These characteristics affect the relationship of the dependent and independent variables. For this purpose this study included firm dummies. A similar model is used by Shah (2011) for the cash holding determinants and Kuan et al. (2009) used a similar model for testing the relationship that poorly governed firms have more cash and experience agency problems.

\subsubsection{The Random Effects Regression Model}

The rationale for random effects regression model is that the variation across groups is assumed to be random and uncorrelated with the independent variables included in the study. This approach controls the differences in the variance of the error term to model groups together, assuming constant intercept and slopes. Some problems with this model are that some variables may not be available in the study that can lead to omitted variable bias. In addition this model involves in consistent estimates that arise from the correlation between individual effects and other independent variables (Greene, 2006).

\subsubsection{Hausman Test}

Hausman test is used to a model that gives the best result and best fits the data. It was developed by Hausman (1978). The Hausman test has a null hypothesis that fixed effects and random effects estimators do not differ systematically. If the null hypothesis is rejected, then the fixed effects model is the best model. If the P-value is less than the significance level at $1 \%, 5 \%$, or $10 \%$, then null hypothesis is rejected(Greene, 2006).

This section considers the sample selection of data and its sources. Along with it a detailed discussion on the variables used in the study is provided. Similarly the statistical model that will be used in the following section is discussed.

\section{Data Analysis \& Findings}

The section discusses various tests that are used for analyzing the data of study. The results of the model that fits the data are also discussed along with the effect of independent variables on dependent variable and the rationale for each of the relationship among variables. 


\subsection{Summary Statistics of Data}

The analysis begins with the summary statistics of the variables used in the study. Table 4.1 reports the summary statistics of data. It presents the names of the variables in its first column, their mean, standard deviations, minimum and the maximum values in the second, third, fourth and fifth columns, respectively. The summary statistics helps to give the readera feel of the data and highlights the existence of outliers. At first when the summary statistics were obtained, values above 99 percentile and below 1 percentile were removed. Also unreasonably higher values were removed for a couple of variables. For example, those firms that have cash of more than $98 \%$ were excluded from the study, and the reason being that cash is not the only asset that the firm should hold. So such values were excluded from data to make generalization of the results possible. Similarly for the other variables such as cash flows, the study dropped the observations if the cash flows were less than -1 and greater than +1 . Similarly, for the leverage 195 observations were dropped where the leverage value was greater than 1 . Theoretically, leverage must be less than 1 in order to remain solvent.

Table 4.1 shows the summary statistics after removal of outliers. On an average, firms in Pakistan hold $4.9 \%$ cash $(C A S H)$ with them. The directors (DIRC) have $29.45 \%$ of the total shares of the firms. Institutional shareholdings (INST) are $34.13 \%$ on an average. The concentration of shares(CON) and the number of board of directors (BOARD) is 7.06 and 7.87, respectively. The ownership percentage of 5 big shareholders $(B I G)$ of the firms in Pakistan is on average 29\%. The increase in the total assets (GROWTH) of firms is on average $35 \%$. Pakistani firms have $59 \%$ of the debt (LEVE) with them on an average. Other variables such as capital expenditure, net- working cash and the cash flows are $71 \%,-.014 \%$ and $98 \%$ respectively.

One of the most important assumptions before estimating regression is that the independent variables do not have high collinearity (Gujarati, 2003). Table 4.2 presents the correlation matrix of the variables. It reveals that independent variables do not have multicolinearity.

Similarly Table 4.3 reports the variance inflation factor (VIF). The mean value of VIF in the study is 1.44 so this means that the data has no problem of multicolinearity among its variables. When the VIF $>10$ then the data has multicolinearity.

\subsection{Regression Results}

\subsubsection{Simple OLS Regression}

The empirical findings of the simple OLS regression are reported in Table 4.4. The first column of the table represents the independent variable of the study. In the second column the coefficients of independent variables are given and the standard errors are given within the parenthesis. The significance levels of $1 \%, 5 \%$ and $10 \%$ are denoted by ${ }^{*}, * *$, and *** respectively. The overall validity of the model is good as shown by the F statistic of 50.06 , with $\mathrm{p}$-value of 0.000 and the $\mathrm{R}^{2}$ value is 0.2266 . This $\mathrm{R}^{2}$ shows the ratio of variation in the dependent variable explained by variation in the independent variables. The table shows that the variables growth (GROWTH) and the log size (LOGSIZE) are insignificant. The directors' ownership and board size are the only independent variables that are negatively related to the cash holdings of the Pakistani firms. Leverage, capital expenditure, and net working capital to cash are the control variables that inversely relate to the dependent variable of the study. Therefore the relationships are discussed in more detail in the fixed effects dummy regression. 


\subsubsection{Hausman Test for Fixed and Random Effects}

In this study both the fixed and random effects model were tested for the data. However to select form the two models Hausman test is used. It checks a more efficient model against a less efficient but consistent model to make sure that the more efficient model also gives consistent results.

Since p-value of the Hausman test in the study is less than 0.05 (Prob $>$ chi $2=$ 0.0000 ), it suggests that the estimates of fixed and random effects models have systematic differences (Greene, 2006 and Cameron, 2007). So the null hypothesis is rejected that is the random effects model is good. Contrary to this, the alternative hypothesis is accepted. Therefore fixed effects model is used in this study as shown by the results of this test.

\subsubsection{Fixed Effects Dummy Variable Regression}

Table 4.6 shows the result of fixed effects regression. This model takes the dummy variables for all the 309 firms in the sample to obtain the results of the regression. In table 4.6 independent variables and their signs are shown. The dummies for each firm are not shown as there were 309 dummy variables for each firm. The first column of the table represents the independent variables of the study. In the second column the coefficients of independent variables are given and the standard errors are given within the parenthesis. The significance levels of $1 \%, 5 \%$ and $10 \%$ are denoted by $*, * *$, and $* * *$, respectively. The total numbers of observations included are 2063. The value of F statistic is 15.13 that indicate that model fits the data. As the value of $\mathrm{R}^{2}$ shows the ratio of variation in the dependent variable explained by variation in the independent variables, it suggests that there is $70 \%$ variations in the dependent variable $(\mathrm{CASH})$ is due to independent variables in the study.

The result of the fixed effects dummy regression shows that the coefficient of directors' ownership (DIRC) is -0.01715 . This shows that the ratio of cash decreases by 0.01715 units when there is one unit increase in the directors' ownership (Table 4.6). The results of this study are consistent with the literature which suggests that if managerial ownership increases the cash holdings of the firm will decrease. According to Jensen (1986), a high level of managerial ownership reduces the agency problems where managerial incentives to expropriate wealth away from shareholders through building of cash reserves decreases. Results of this study are also consistent with evidence from UK firms as reported by Ozkan and Ozkan (2004). Similar results were reported by Ehikioya and Yuanjian (2009) for a sample of Nigerian firms.

The institutional shareholding(INST) is another proxy for governance mechanism used in study. An increase of this variable by one unit increases the cash held by a firm by 0.0521 units (Table 4.6). In Pakistan mostly the firms are owned by families or by the institutions (Cheema et al.,2003). This decreases the agency problems as the interest of managers and shareholders are aligned but this results in the conflict between the insider and the outsider shareholders. Maintaining alarge amount of cash by the insiders is doneby reducing the dividend payments (Jensen and Meckling, 1976). Literature shows that the shareholders rights are not protected by law of the country like Pakistan. Thus the insider large shareholders who are also managing the firms (Ibrahim, 2005) cannot be forced by the minority outside shareholders to pay the dividend as they have fewer rights and less protection. The majority shareholders expropriate the minority shareholders and will pay fewer dividends. According to the investor power hypothesis, in the country where the legal system is not powerful, the factor that determines dividends payments is the powerful outside 
investors who can force firms to pay the dividends (Abdullah et al. 2011). But in Pakistan the outside shareholders have less power compared to the majority inside shareholders. In addition to this the minority investors are reluctant to invest in the firms where there is more control of the majority inside shareholders. The present study findings show that more institutional shareholdings results in more cash holdings by the firms is consistent with the findings of the Harford et al. (2006) who found a positive association between the insider ownership and the cash holdings in US firms. In addition to this because of the liability structures of the institutional shareholdings they may be required to hoard more cash so as to have stable dividend payments. Thus these dividend paying firms hold cash to pay the dividends and high institutional shareholdings.

The results show that one unit increase in the concentration of shares (CON) brings about 0.0046 units increase in the dependent variable (Table 4.6). In other words, if the number of shareholders increases the cash holdings would increase and thus the concentration of ownership decreases. According to La Portaet al.(1998, 1999 and 2000), countries with weak legal environment, as in Pakistan the founders tries to maintain large positions in their firms which results in concentration of ownership in these firms and thus they also maintain high cash reserves with them to avail the profitable opportunities. These founders use the firm resources cash reserves for extracting their private benefits as they have control over the firm and the cash held by it. The minority shareholders are not protected as the insider majority shareholders enjoy their full power over the firm. In addition they monitor and control the activities of the managers in a better way (Demsetz, 1983; Shleifer and Vishny, 1986).

The coefficient of (BOARD) is negative and statistically significant (Table 4.6). The results indicate that one unit increase in size of the board (BOARD) brings -0.0091 unit decrease in the cash holdings of a firm. This finding is consistent with that of Harford et al. (2006) who found an inverse relationship between the board size and the cash holdings of the firm. The board of directors is an important part of a firm's monitoring mechanism. Members of the board are responsible for monitoring and evaluation of senior management of a firm. When the number of directors on the board in firm increases it leads to more monitoring and control over the management and the policies made by the directors. Consequently the cash held by the firms' decreases. The finding of present study is inconsistent with the results of Lee and Lee (2010) who found that the larger board proves to be more inefficient and also possess the problems of coordination. In another study by Yermack (1996) finds that smaller boards are more efficient as they provide better and effective decision making.

The variable $(B I G)$ has positive and significant relationship with cash holdings of the sampled firms (Table 4.6). The results indicate that one unit increase in percentage of shareholdings by 5 big shareholders $(B I G)$ increase the cash by 0.0374 units. As the previous results of the study indicate that when concentration of shares increase consequently percentage of shares held by 5 largest shareholders increases, therefore they will have more power and will hoard more cash with them. In a country like Pakistan with weak shareholders protection, it is difficult and costly to raise external financing. Due to high interest charged on the amount borrowed and also failure to repay the previous debt increases the risk related to the business therefore minority investors are also reluctant to invest. If the firm is unable to return its debt back it will go bankrupt and thus by law no such regulations are made for the protection of the minority shareholders. Thus they are not willing to pay more equity and debt due to lack of protection (La Porta et al., 1999). Therefore the ownership percentage of 5 largest shareholders of Pakistani firms hold more cash so as they can avail any profitable 
opportunities (Dittmar et al., 2003). These results are inconsistent with Kusnadi (2006) findings who reported a negative relationship between the non-executive larger shareholders of the firms and cash in the Singapore and the Malaysian firms. The variable growth (GROWTH) has a positive insignificant relationship with the cash holdings (Table 4.6). This indicates that growing firms in Pakistan do not hold excess cash with them.Consistent with the literature the control variable size (LOGSIZE) is found to be inversely and insignificantly related to cash holdings of the firms (Kim et al., 1998 and Opler et al., 1999). This means that the larger firms hold less cash (Dittmar et al., 2003), they have economies of scale to manage cash (Miller and Orr, 1966) and are diversified therefore they have less chance of going bankrupt (Rajan and Zingales, 1995). However the findings are inconsistent with the studies in Pakistan by Afza (2009) and Shah (2011), who found that the firm size is related directly and significantly to the cash holdings of the firms. There is a positive relationship between cash holdings and cash flows (CASHFLOWS)(Table 4.6). This is similar to the findings of Dittmar et al. (2003), Kalcheva and Lins (2007) and Kim et al. (1998). The result of this study shows that high cash flows are more likely to result in the dividends payments. This is because the dividends and the cash holdings are related directly so the present study can conclude that the increase cash flows can be for the dividend payments. As Opler et al. (1999) found that large firms are more profitable and can accumulate cash and thus will hold high levels of dividends that act as a substitute for cash for firms. In addition to this high cash flows resulting in high cash holdings by firms might also be to avail the profitable opportunities, to avoid bankruptcy, to provide a cushion for smooth operations of firms and to finance their investments. The result is consistent with findings of the studies in Pakistan by Shah (2011), Azmat (2011) and Afza (2009). Furthermore inconsistent with findings of Opler et al. (1999) and Harford et al. (2003) but consistent with findings of Ammann et al. (2011), the study concludes that the dividend (DIVDUM) is related positively to cash holdings of the firms in Pakistan (Table 4.6).The dividend payments reduces the possibility for managers to waste cash for projects that have negative net present value (Ammann et al.,2011).The dividend theories suggest that firms pay dividends according to certain pattern. Thus the dividend paying firms have to maintain larger cash balances for paying dividends. The findings of the present study are in line with the study in Pakistan by Shah (2011) and are contrary to findings of Afza (2009), from this it can be concluded that the dividends can be used as a substitute for cash if they are not paid by the firms.

The relationship between leverage (LEVE) and cash holdings is negative (Table 4.6). This is consistent with Ozkan and Ozkan (2004),Afza (2009) and Azmat (2010) but is different from the findings of Opler et al. (1999) who find a positive relationship. This suggests that firms that have high debt will in turn have less liquid assets. Debt is as a substitute of cash for the firms, when firms need the cash they can borrow it but only if the firm has the ability to borrow. This relationship is also consistent with pecking order and free cash flow theories. As according to the pecking order theory, when firms' investments are in excess of retained earnings the negative relationship occurs between the leverage and cash holdings. Similar relationship is supported by free cash flow theory that firms are monitored by capital markets and prevent higher managerial control (Kalcheva and Lins, 2003).

The results indicate that one unit increase in capital expenditure (CAPEX) brings0.0192 units decrease in the cash holdings (Table 4.6). This means that the more liquid assets there are, the more cash is held by the Pakistani firms and the less they will invest in the long term assets like the fixed assets. The ratio of cash net working capital (current assets minus current liabilities minus cash) to total assets $\left(\mathrm{NW}_{-} \mathrm{CASH}\right)$ is -0.1469 . The inverse relation 
between the cash holdings and net-working suggests that the cash holdings and the net working capital are the close substitutes of cash for firms (Dittmar et al., 2003). This relationship is contrary to the tradeoff theory and to the studies by Opler et al. (1999) and Ozkan and Ozkan (2002). The reason for this inconsistency with the tradeoff theory and the other studies can be high cost of external debt in Pakistan(Kalcheva and Lins, 2003). Consistent with the study of Afza and Adnan (2009) the result of the study is in support of the pecking order theory. This theory suggests that firms for the financing of the investments first use the retained earnings and then use debt.

\subsubsection{Random Effects GLS Regression}

To strengthen the selection of fixed effects model used in the present study, results of the random effects model are also observed. Random effects model is another technique used for the panel data analysis. In Table 4.7 the corr $(\mathrm{u} i, \mathrm{X})=0$ means that in the random effects model the differences across entities are uncorrelated with the independent variable. The value of Rho is $55 \%$ that means that $55 \%$ of the variance is due to differences across panels. The omitted variables effects are also observed in this model. Both the models of the panel regression that are fixed and random effects model suit the data well. However the Hausman test assist in selection of the model fixed effects for the dummy variable. Therefore fixed effects modelis used and preferred in present study for the analysis of the data.

\subsubsection{Cross Sectional Regression}

Finally for further supporting fixed effects model the cross sectional regression Table 4.8 on the data checks that either it gives the significant results. In this model the dependent and independent variables are associated with one period or point in time. For all the firms in the study the average values of the variables are found instead of the time series values. The observations are independent, thus the estimates of the OLS regression will be unbiased, consistent and efficient. One drawback of this model is that it does not take into account the changes in variables over a period of time.

Table 4.8 shows the results of the cross regression and thus it leads towards using the fixed effects model, a panel data technique that takes into consideration the dependent and independent variables of 309 firms over a time span of 2002 to 2010. The model that bests first the data set of the present study is the fixed effects model.

\section{Conclusion}

The main objective of the present study was to test the impact of several corporate governance proxies and control variables on the decision to hold cash in non-financial listed firms on KSE in Pakistan. Consistent with the previous studies, the present study used proxies for the corporate governance that include institutional share holdings, director's ownership, ownership concentration, board size and ownership percentage of 5 big shareholders. The results and discussion in the preceding section reveal two main findings (i) director's ownership and board size are negatively related with corporate cash holdings while (ii) the institutional shareholdings, concentration of shares and the ownership percentage of 5 big shareholders are directly related to cash holdings.

The findings of the present study suggest that increase in directors' ownership would decrease cash holdings. This implies that agency problems can be reduced if managers are given more stakes in the firm. As managerial ownership increases, managers will not misuse the firm resources and will try to put each asset to best economic use. Since cash is the least 
productive asset, owner-managers will try to hold less and less cash, keeping other things constant. According to the literature, firms that hold less cash have good governance. Thus this implies that as managerial control increase, Pakistani firms hold less cash that is the least productive asset and therefore they might in turn have good governance mechanisms. Similarly as the board size increases, cash holdings decrease. This implies that larger boards are effective in controlling managers from hoarding unnecessary cash. Thus, the results indicate that larger boards are better at monitoring the manager's activities. Collectively the two findings of the study imply higher managerial ownership or larger boards can be alternate ways of corporate governance in Pakistan. In addition to the above findings there is positive association between institutional shareholdings and cash holdings. One reason might be that institutional shareholders desire steady flow of dividends due to their liability structures, which is why firms with higher intuitional shareholdings pay regular dividends and maintain more cash wherefrom the dividend can be paid. Similarly there is positive association between cash holdings with both the concentration of shares and ownership percentage of 5 big share holders. The control variable growth has a positive but insignificant relationship with the cash holdings. This implies that the growing firms in Pakistan do not hold more cash with them. Similarly the variable size is negatively but insignificantly related to cash holdings of the firms. The advantage for why larger firms hold less cash might include economies of scale to manage cash and that large firms are diversified thus they need less cash to avoid bankruptcy. Results also indicated a positive relationship of cash flow cash holdings with and dividends. These results imply that high cash flows are more likely to result in the dividend payments by the firms to shareholders. Dividends act as a substitute of cash for firms. The dividend payments reduce the chance for managers to waste cash for unnecessary projects. Cash flows also enable firms to avail the profitable opportunities, to avoid bankruptcy, to provide support for smooth operations of firms and to finance investments. While the relationship between the leverage and cash holdings are negative. This suggests that firms that have high debt will in turn have less liquid assets. Debt is as a substitute of cash for the firms. When firms need the cash they can borrow it but only if the firm has the ability to borrow. Similarly there is negative association between net-working and capital expenditure with cash holdings of firms. This implies cash and net working capital are the close substitutes of each other and that firms hold more liquid assets and invest less in fixed assets.

\section{Limitations of the Study}

The limitation of the study is that only the firms listed on the KSE are included in the analysis. Financial firms are excluded due to the differences in capital structures. After excluding the outliers from the data, the study includes 309 non- financial listed firms on the KSE from all the sectors. The firms that have negative cash holdings and firms that have not given their corporate governance data are not included in the study. In addition to this, the data covers the time period ranging from 2002 to 2010. The data from 2002 is included in this study as the code of corporate governance was implemented on the firms in Pakistan from this year and the governance data is available from 2002 onwards. Moreover the firms in Pakistan do not show the data for some of the important variables of corporate governance like the family ownership variable, so all such variables are excluded from the study. Some firms have also not given their annual reports from which the required data can be extracted. They are also excluded from the data set. Likewise the study did not use the qualitative data i.e. the interviews could also be used for analyzing this data. 


\section{Future Research}

The present study has studied the relationship between the cash holdings and the corporate governance in firms in Pakistan. So the researchers are encouraged to further analyze different aspects of this relationship in Pakistani firms. There is a need to consider this relationship and its impact on the performance of the firms in Pakistan. Moreover, to extend the work to cross country analysis especially analyzing the impact of corporate governance on cash holdings and comparing it among the developing countries and other developed countries of world is also a prospect worthy of research. It is expected that more research will be conducted in this potential area in future in Pakistan that will strengthen the findings and results of the present study. 崖数

\section{References}

Afza, T. \& Adnan, S.M. (2007). Determinants of Corporate Cash Holdings: A Case Study of Pakistan .Singapore Economic Review Conference (SERC), Organized by Singapore Economics Review and the University of Manchester (Brooks World Poverty Institute), 164165.

Ammann, M., Oesch, D. \& Schmid, M. (2010). Cash Holdings and Corporate Governance Around the World. Journal of Empirical Finance, forthcoming.

Azmat, A. (2011). Corporate Cash Holdings: A Growth and Mature Firm Perspective in Pakistani Context.3rd International SAICON Conference.

Cheema, A., Bari, F. \& Siddque, O. (2003). Corporate Governance in Pakistan: Ownership, Control and the Law. Lahore University of Management Sciences, Lahore.

Chen, R. (2008). Corporate Governance and Cash Holdings: Listed New Economy versus Old Economy Firms. Corporate Governance: An International Review 16 (5), 430-442.

Dittmar, A., Smith, J. M. \&Servaes, H. (2003).International Corporate Governance and Corporate Cash Holding. Journal of Financial and Quantitative Analysis 38(1), 111-133.

Ehikioya,B.I. \&Yuanjian, Q. (2007). The Effect of Corporate Governance Structure on Corporate Cash Holdings: An Empirical Analysis of Nigerian Listed Firms. School of Management, Wuhan University of Technology, 430070, P. R. China.

Gibson, M. S. (2002). Is Corporate Governance Ineffective in Emerging Markets?Journal of Financial and Quantitative Analysis, 2003.

Ginglinger, E.\&Saddoura, K. (2007). Cash holdings, Corporate Governance and Financial Constraints. Working Paper.

Gupta, A., Gupta, S.L. \& Hothi, B.S. (2011).Corporate Governance in India.Global Journal of Management and Business Research 11(5), 9-16.

Harford, J., Mansi, S. \& Maxwell, W. (2008).Corporate Governance and Firm Cash Holdings in the US. Journal of Financial Economics 87(3), 535-555.

Javid, A.Y. \& Iqbal, R. (2009). Ownership Concentration, Corporate Governance and Firm Performance: Evidence from Pakistan. The Pakistan Development Review 48(4).

Javid, A.Y.\& Iqbal, R. (2010).Corporate Governance in Pakistan: Corporate Valuation, Ownership and Financing. Working Papers, PIDE. 
Jensen, M. (1986). Agency costs of the Free Cash flow, Corporate Finance and Takeovers. American Economic Review 76, 323-329.

Jensen, M.C. \&Meckling, W. H. (1976). Theory of the Firm: Managerial Behavior, Agency Costs and Ownership Structure. Journal of Financial Economics 3, 305-360.

Johnson, S. et al. (1999).Corporate Governance in the Asian Financial Crisis. Journal of Financial Economics 58, 141-186.

Kalcheva, I.\&Lins, K. V. (2003).International Evidence on Cash Holdings and Expected Managerial Agency Problems. Working Paper, SSRN.

Keynes, J. M. (1936). The General Theory of Employment. Interest and Money, London: McMillan.

Kim, C. S., Mauer, D. C. \&Sherman, A.E. (1998). The Determinants of Corporate Liquidity: Theory and Evidence. Journal of Finance 33(3), 335-359.

Kusnadi, Y. (2003). Corporate Cash Holdings, Board Structure, and Ownership Concentration: Evidence from Singapore. Working Paper, SSRN.

Kusnadi, Y. (2011). Do Corporate Governance Mechanisms Matter for Cash Holdings and Firm Value? Pacific-Basin Finance Journal 19,554-570.

La Porta, et al. (2000).Investor Protection and Corporate Governance. Journal of Financial Economics 58, 3-27.

Lee, K.W. \& Lee, C.F. (2009).Cash Holdings, Corporate Governance Structure and Firm Valuation.Review of Pacific Basin Financial Markets and Policies 12(03), 475-508.

Mir, S. R. \& Nishat, M. (2004).Corporate Governance Structure and Firm Performance in Pakistan- an Empirical Study. Second Annual Conference in Corporate Governance.University of Management Sciences, Lahore.

Naqvi, A. \& Ikram, A. (2004). Group Affiliation, Firm Performance and Corporate Governance in Pakistan: Evidence from the Textile Sector. LUMS-SEC Conference on Corporate Governance in Pakistan: Regulation, Supervision, and Performance. University of Management Sciences Lahore.

Opler, et al. (1999). The Determinants and Implications of Cash Holdings. Journal of Financial Economics 52(1), 3-46.

Ozkan, A. \&Ozkan, N. (2004). Corporate Cash Holdings: An Empirical Investigation of UK Companies. Journal of Banking and Finance 2, 2103-2134.

Paskelian, O.G., Bell, S. \& Nguyen, C.V. (2010). Corporate governance and cash holdings: A comparative analysis of Chinese and Indian firms. The International Journal of Business and Finance Research 4(4), 59-71.

Ping, T., Qing, S. C. \& Li, S. (2011). Empirical Research on the Interactive Relationship between Cash Holdings and Corporate Performance of Listed Companies in China.In Management Science and Engineering (ICMSE).International Conference on IEEE, 938-949. 
Pinkowitz, L., Stulz, R. \&Williamson, R. (2006). Does the Contribution of Corporate Cash Holdings and Dividends to Firm Value Depend on Governance? A Cross-country Analysis.Journal of Finance 61, 2725-2751.

Saddour, K. (2006). The Determinants and the Value of Cash Holdings: Evidence from French firms. Working Paper, Dulphine University Paris.

Schauten, B.J., Dijk, D.V. \& Waal, J.P. (2011).Corporate Governance and the Value of Excess Cash Holdings of Large European Firms. Working Paper.

Shah, A. (2011). The Corporate Cash Holdings: Determinants and implications. African Journal of Business Management 5(34), 12939-12950.

Soltani, A. \&Ravanmehr, N. (2011).Corporate Governance, Cash Holdings and Firm Value on the Tehran stock exchange. Annual Summit on Business and Entrepreneurial Studies (ASBES) Proceeding.

Tsai, C.C. (2012). Cash Holdings and Corporate Governance in Business Group Affiliated Firms. International Conference on Economics Marketing and Management 28, 83-86.

Valipour, H. et al. (2012). Corporate Governance and Cash Holdings Policies: Evidence from Iran. American Journal of Scientific Research 44, 153-162.

Varma, J.R. (1997). Corporate Governance in India: Disciplining the Dominant Shareholder. The Journal of the Indian Institute of Management, Bangalore 9(4), 5-18.

Zhang, R. (2005). The Effects of Firm- and Country-level Governance Mechanisms on Dividend Policy, Cash Holdings, and Firm Value: a Cross-country Study. Working Paper.

Table 3.1: Names and Measurements of the Variables

\begin{tabular}{|c|c|c|}
\hline Names of Variables & Symbols & Measured by \\
\hline Cash holdings & $C A S H$ & $\begin{array}{l}\text { A ratio of cash and cash equivalents to net assets. Net assets } \\
\text { are computed as total assets less cash and cash equivalents. }\end{array}$ \\
\hline Institutional Shareholders & $I N S T$ & It is the shares held by the institutional investors. \\
\hline Directors Ownership & DIRC & $\begin{array}{l}\text { It is the shares held by the directors divided by the total } \\
\text { number of shares. }\end{array}$ \\
\hline Concentration & $C O N$ & It is the log of the number of shareholders. \\
\hline Board Size & $B O A R D$ & The number of directors on the board. \\
\hline Large Shareholders & $B I G$ & The shares held by the 5 largest shareholders of the firm. \\
\hline Growth & GROWTH & $\begin{array}{l}\text { It is the geometric mean of the percentage increase in the } \\
\text { total assets. }\end{array}$ \\
\hline Dividend & DIVDUM & $\begin{array}{l}\text { Dividend is a dummy variable. The firms that pay dividend } \\
=1 \text { and those not paying dividend }=0\end{array}$ \\
\hline Size of Firm & LOGSIZE & The log of total assets. \\
\hline Leverage & LEVE & It is the ratio of total liabilities to total assets. \\
\hline Capital Expenditure & CAPEX & It is the percentage increase in the gross fixed assets. \\
\hline Net Working Capital & $N W_{-} C A S H$ & $\begin{array}{l}\text { The ratio of Current assets minus cash minus current } \\
\text { liabilities to total assets is the networking capital. }\end{array}$ \\
\hline Cash Flows & CASHFLOWS & $\begin{array}{l}\text { It is the ratio of addition net income and depreciation to total } \\
\text { assets. }\end{array}$ \\
\hline
\end{tabular}


Table 4.1: Summary Statistics

\begin{tabular}{|l|c|c|c|c|}
\hline Variables & Mean & Std.Dev & Minimum & Maximum \\
\hline CASH & 0.0493 & 0.0887 & 0.0000 & 0.6901 \\
\hline DIRC & 0.2959 & 0.2828 & 0.0000 & 0.9774 \\
\hline INST & 0.3413 & 0.2656 & 0.0000 & 0.9817 \\
\hline CON & 7.0601 & 1.5255 & 0.0000 & 11.3217 \\
\hline BOARD & 7.8742 & 1.4514 & 7.0000 & 15.0000 \\
\hline BIG & 0.2990 & 0.3382 & 0.0000 & 0.9924 \\
\hline GROWTH & 0.3542 & 3.6720 & -0.1446 & 88.2150 \\
\hline DIVDUM & 0.4876 & 0.4999 & 0.0000 & 1.0000 \\
\hline LOGSIZE & 7.5032 & 1.6055 & 2.7508 & 12.3409 \\
\hline LEVE & 0.5908 & 0.2066 & 0.0138 & 0.9987 \\
\hline CAPEX & 0.0713 & 0.1600 & -0.9356 & 1.5408 \\
\hline NW_CASH & -0.0014 & 0.2215 & -0.9213 & 0.8064 \\
\hline CASHFLOWS & 0.0986 & 0.1460 & -0.9457 & 1.9521 \\
\hline
\end{tabular}

Table 4.1 presents summary statistics of the data after removal of outliers. The sample included 309 firms listed on the KSE over the period from 2002 to 2010 . The total number of observations after removing the outliers are 2063.The dependent variable is cash $(C A S H)$ which is the ratio of cash and cash equivalents to the net assets (total assets less the cash and cash equivalents). The independent variables include directors ownership (DIRC), calculated as the shares held by the directors divided by the total number of shares. The institutional shareholder (INST) is the shares held by the institutional investors. The ownership concentration (CON) is the log of the number of share holders. The number of directors on the board (BOARD) refers to the shares held by the 5 largest shareholders of the firm $(B I G)$ divided by total shares of the firm. The variable growth is the geometric mean of the percentage increase in the total assets (GROWTH). Dividend is a dummy variable. In firms that pay dividend, the DIVDUM=1 and elsewhere it is 0 . The (LOGSIZE) is log of total assets. Leverage is the ratio of total liabilities to total assets (LEVE). Capital expenditure is the percentage increase in the gross fixed assets (CAPEX). The ratio of current assets minus cash minus current liabilities to total assets is the networking capital ( $\left.N W_{-} C A S H\right)$. The variable cash flows (CASHFLOWS) is the ratio of addition net income and depreciation to the total assets.

Table 4.2: Correlation Matrix

\begin{tabular}{|c|c|c|c|c|c|c|c|c|c|c|c|c|c|}
\hline & CASH & $\begin{array}{l}\text { CASH } \\
\text { FLOWS }\end{array}$ & DIRC & CON & INS & BOARD & BIG & LOGSIZE & LEVE & CAPEX & DIVDUM & GROWTH & NW_CASH \\
\hline CASH & 1 & & & & & & & & & & & & \\
\hline $\begin{array}{l}\text { CASH } \\
\text { FLOWS }\end{array}$ & 0.2656 & 1 & & & & & & & & & & & \\
\hline DIRC & -0.222 & -0.162 & 1 & & & & & & & & & & \\
\hline $\mathrm{CON}$ & 0.158 & 0.045 & $\overline{0.255}$ & 1 & & & & & & & & & \\
\hline INS & 0.225 & 0.115 & $\overline{0} .597$ & 0.300 & 1 & & & & & & & & \\
\hline$B O A R D$ & 0.089 & 0.135 & $\overline{0} .198$ & 0.316 & 0.187 & 1 & & & & & & & \\
\hline BIG & 0.105 & 0.008 & $\overline{0.146}$ & 0.133 & $\overline{0} .089$ & 0.123 & 1 & & & & & & \\
\hline $\begin{array}{l}\text { LOGSIZ } \\
E\end{array}$ & 0.1353 & 0.086 & $\overline{0.286}$ & 0.544 & 0.311 & 0.371 & 0.1950 & 1 & & & & & \\
\hline$L E V E$ & -0.216 & -0.289 & 0.179 & 0.048 & $\overline{0.189}$ & -0.040 & 0.020 & -0.0188 & 1 & & & & \\
\hline CAPEX & -0.052 & 0.014 & 0.037 & $\overline{0.006}$ & $\overline{0} .023$ & 0.020 & 0.003 & 0.0716 & -0.007 & 1 & & & \\
\hline $\begin{array}{l}D I V D U \\
M\end{array}$ & 0.246 & 0.369 & $\overline{0.170}$ & 0.053 & 0.188 & 0.200 & 0.050 & 0.2499 & -0.271 & 0.023 & 1 & & \\
\hline $\begin{array}{l}\text { GROWT } \\
H\end{array}$ & -0.016 & -0.031 & 0.063 & 0.007 & $\overline{0} .037$ & 0.036 & -0.028 & 0.0697 & 0.041 & 0.042 & $-0,020$ & 1 & \\
\hline $\begin{array}{l}N_{W_{-}} C A \\
S_{-}\end{array}$ & 0.005 & 0.197 & $\overline{0}-193$ & - & 0.142 & -0.029 & -0.019 & -0.0249 & -0.618 & -0.107 & 0.284 & -0.024 & 1 \\
\hline
\end{tabular}


Table 4.3: Variance Inflation Factor

\begin{tabular}{lll}
\hline \multicolumn{1}{c}{ Variables } & VIF & $\mathbf{1 / V I F}$ \\
\hline DIRC & 1.74 & 0.5760 \\
$I N S T$ & 1.79 & 0.5573 \\
CON & 1.56 & 0.6395 \\
BOARD & 1.23 & 0.8127 \\
BIG & 1.13 & 0.8812 \\
GROWTH & 1.02 & 0.9815 \\
DIVDUM & 1.35 & 0.7430 \\
LOGSIZE & 1.71 & 0.5830 \\
LEVE & 1.76 & 0.5685 \\
CAPEX & 1.04 & 0.9658 \\
NW_CASH & 1.77 & 0.5634 \\
CASHFLOWS & 1.23 & 0.8132 \\
\hline Mean VIF & $\mathbf{1 . 4 4}$ & \\
\hline
\end{tabular}

Table 4.4: Simple OLS regression

\begin{tabular}{|l|c|}
\hline \multirow{2}{*}{ Dependent Variable } & Independent Variable \\
\cline { 2 - 2 } & Coefficients \\
\hline DIRC & $-0.0290(0.00792)^{* * *}$ \\
\hline CON & $0.0361(0.00857)^{* *}$ \\
\hline BOARD & $0.0046(0.00139)^{*}$ \\
\hline BIG & $-0.0036(0.00129)^{* *}$ \\
\hline GROWTH & $0.0241(0.00533)^{* *}$ \\
\hline DIVDUM & $0.0004(0.00043)$ \\
\hline LOGSIZE & $0.0212(0.00402)^{* *}$ \\
\hline LEVE & $-0.0019(0.00138)$ \\
\hline CAPEX & $-0.0982(0.01099)^{* *}$ \\
\hline NW_CASH & $-0.0475(0.01076)^{* *}$ \\
\hline CASHFLOWS & $-0.1151(0.01031)^{* *}$ \\
\hline
\end{tabular}

Table 4.4 describes the fixed effects dummy variable regression. The study contains 309 listed firms on KSE covering a time span of 2002 to 2010. The standard errors are in the parenthesis and $*, * *, * * *$ represents the $1 \%, 5 \%$ and $10 \%$ significance level respectively. The variables GROWTH and LOGSIZE are insignificant variables.The dependent variable cash $(\mathrm{CASH})$ is the ratio of cash and cash equivalents to the net assets (total assets less the cash and cash equivalents). The independent variables are directors ownership (DIRC) is the shares held by the directors divided by the total number of shares. The institutional shareholder (INST) is the shares held by the institutional investors. The ownership concentration (CON) is the $\log$ of the number of share holders. The number of directors on the board is another independent variable (BOARD). the shares held by the 5 largest shareholders of the firm $(B I G)$. The variable growth is the geometric mean of the percentage increase in the total 
assets (GROWTH). First calculate the total assets yearly increase and then calculate its geometric mean of this. The control variable dividend is a dummy variable. The firms that pay dividend $=1$ and those not paying dividend $=0(D I V D U M)$. The $\log$ of total assets is the size of firm (LOGSIZE). Leverage is the ratio of total liabilities to total assets (LEVE). Capital expenditure is the percentage increase in the gross fixed assets (CAPEX). The ratio of current assets minus cash minus current liabilities to total assets is the networking capital $\left(N W_{-} C A S H\right)$. The variable cash flows (CASHFLOWS) is the ratio of addition net income and depreciation to the total assets.

Table 4.5:Hausman Test for Fixed and Random Effects

\begin{tabular}{lllll}
\hline Variables & Fixed & Random & Difference & Std. Err \\
\hline DIVDUM & 0.0021 & 0.0066 & -0.0045 & 0.0007 \\
LOGSIZE & -0.0159 & -0.0071 & -0.0088 & 0.0019 \\
LEVE & -0.0699 & -0.0817 & 0.0118 & 0.0054 \\
CAPEX & -0.0192 & -0.0232 & 0.0040 & - \\
NW_CASH & -0.1469 & -0.1366 & -0.0102 & 0.0031 \\
CASHFLOWS & 0.1198 & 0.1382 & -0.0184 & 0.0039 \\
\hline
\end{tabular}

Table 4.6: Fixed Effects Regression

\begin{tabular}{|l|l|}
\hline Independent variable & Coefficients \\
\hline DIRC & $-0.1715(0.1005)^{* *}$ \\
\hline INST & $0.0521(0.0542)^{* *}$ \\
\hline$C O N$ & $0.0046(0.0062)^{*}$ \\
\hline BOARD & $-0.0091(0.0068)^{* * *}$ \\
\hline BIG & $0.0374(0.00377)^{* *}$ \\
\hline GROWTH & $0.0007(0.0007)$ \\
\hline DIVDUM & $0.0021(0.0033)^{* *}$ \\
\hline LOGSIZE & $-0.0015(0.0028)$ \\
\hline LEVE & $-0.0699(0.0128)^{* *}$ \\
\hline CAPEX & $-0.0192(0.073)^{* *}$ \\
\hline NW_CASH & $-0.1469(0.0100)^{* *}$ \\
\hline CASHFLOWS & $0.1198(0.0143)^{* *}$ \\
\hline
\end{tabular}

Table 4.6 describes the regression of the dependent and the independent variables along with the control variables. The standard errors are in the parenthesis and $*, * *, * * *$ represents the $1 \%, 5 \%$ and $10 \%$ significance level respectively. The variables growth (GROWTH) and size (LOGSIZE) are insignificant variables. All the other variables are significant at 5\%, 1\%and 10\% level of significance. The dependent variable cash $(\mathrm{CASH})$ is the ratio of cash and cash equivalents to the net assets (total assets less the cash and cash equivalents). The independent variables are directors ownership (DIRC) is the shares held by the directors divided by the total number of shares. The institutional shareholder (INST) is the shares held by the institutional investors. The ownership concentration (CON) is the log of the number of share holders. The number of directors on the board is another independent variable 
$(B O A R D)$.the shares held by the 5 largest shareholders of the firm $(B I G)$. The variable growth is the geometric mean of the percentage increase in the total assets (GROWTH). We first calculate the total assets yearly increase and then calculate its geometric mean of this. The control variable dividend is a dummy variable. The firms that pay dividend $=1$ and those not paying dividend $=0(D I V D U M)$. The $\log$ of total assets is the size of firm (LOGSIZE). Leverage is the ratio of total liabilities to total assets ( $L E V E)$. Capital expenditure is the percentage increase in the gross fixed assets (CAPEX). The ratio of current assets minus cash minus current liabilities to total assets is the networking capital ( $N W$ CASH). The variable cash flows (CASHFLOWS) is the ratio of addition net income and depreciation to the total assets.

Table 4.7: Random Effects GLS Regression

\begin{tabular}{|c|c|}
\hline Independent variable & Coefficients \\
\hline$D I R C$ & $-0.0428(0.01602)^{* * *}$ \\
\hline$I N S T$ & $0.0414(0.01713)^{*}$ \\
\hline$C O N$ & $0.0047(0.00261)^{* * *}$ \\
\hline$B O A R D$ & $-0.0005(0.00261)$ \\
\hline$B I G$ & $0.0237(0.01076)^{* *}$ \\
\hline GROWTH & $0.0004(0.0007)$ \\
\hline DIVDUM & $0.0066(0.00323)^{* *}$ \\
\hline LOGSIZE & $-0.0071(0.00202)^{* *}$ \\
\hline LEVE & $-0.0817(0.01159)^{* *}$ \\
\hline CAPEX & $-0.0232(0.00737)^{* *}$ \\
\hline $\mathrm{NW} C \mathrm{CASH}$ & $-0.1366(0.00955)^{* *}$ \\
\hline CASHFLOWS & $0.1382(0.01381)^{* *}$ \\
\hline \multicolumn{2}{|c|}{ : Cross Sectional Regression } \\
\hline Independent Variables & Coefficients. \\
\hline$\overline{D I R C}$ & $-0.0266(0.01623)^{* * *}$ \\
\hline INST & $0.0264(0.01711)^{* * *}$ \\
\hline$C O N$ & $0.0043(0.00283)^{* * *}$ \\
\hline BOARD & $-0.0036(0.00269)$ \\
\hline$B I G$ & $0.0223(0.01076)^{* *}$ \\
\hline GROWTH & $0.0005(0.00068)$ \\
\hline DIVDUM & $0.0333(0.01263)^{* * *}$ \\
\hline LOGSIZE & $-0.0020(0.00299)$ \\
\hline LEVE & $-0.0774(0.02696)^{* *}$ \\
\hline CAPEX & $-0.1483(0.05832)^{*}$ \\
\hline $\mathrm{NW} \mathrm{CASH}_{-}$ & $-0.0932(0.02806)^{*}$ \\
\hline CASHFLOWS & $0.2016(0.04960)^{* *}$ \\
\hline
\end{tabular}

Table 4.8 presents results for the cross sectional regression. The study contains 309 listed firms on KSE covering a time span of 2002 to 2010. The standard errors are in the parenthesis and $* * *, * * *$ represents the $1 \%, 5 \%$ and $10 \%$ significance level respectively . The variables board (BOARD), size (LOGSIZE) and growth (GROWTH) are insignificant. The dependent variable cash $(\mathrm{CASH})$ is the ratio of cash and cash equivalents to the net assets (total assets less the cash and cash equivalents). The independent variables are directors ownership (DIRC) is the shares held by the directors divided by the total number of shares. 
The institutional shareholder (INST) is the shares held by the institutional investors. The ownership concentration (CON) is the log of the number of share holders. The number of directors on the board is another independent variable (BOARD). the shares held by the 5 largest shareholders of the firm $(B I G)$. The variable growth is the geometric mean of the percentage increase in the total assets $(G R O W T H)$. We first calculate the total assets yearly increase and then calculate its geometric mean of this. The control variable dividend is a dummy variable. The firms that pay dividend $=1$ and those not paying dividend $=0(D I V D U M)$. The log of total assets is the size of firm (LOGSIZE). Leverage is the ratio of total liabilities to total assets ( $L E V E)$. Capital expenditure is the percentage increase in the gross fixed assets $(C A P E X)$. The ratio of current assets minus cash minus current liabilities to total assets is the networking capital (NW_CASH). The variable cash flows (CASHFLOWS) is the ratio of

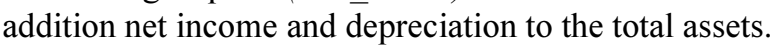

"In sum, I think that we have freedom of will and that it comes out of our uniqueness as individuals, perhaps wholly determined, yet to some degree unpredictable. However limited in scope, it is one of our most precious possessions. As such we should seek to enlarge it; yet that is not the direction in which we are going. On the contrary, many aspects of modern life threaten to erode it; and much that we are offered in the guise of future progress would tend to do the same."

George Wald, New Views of the Nature of Man, p. 46 